$\mathrm{PhD}$ Programme Language and Literature azivanovic131313@gmail.com

\author{
Mirjana D. Subotin \\ University of Novi Sad \\ Faculty of Philosophy \\ $\mathrm{PhD}$ Programme Language and Literature \\ mirjanas93@hotmail.com
}

\title{
THE GOAL SETTING COMPONENTS: A STUDY OF SERBIAN EFL LEARNERS
}

\begin{abstract}
The goal setting theory came into existence almost three decades ago (Locke \& Latham 1990). However, goal setting in Serbian EFL students has not been investigated so far. The aim of this paper is to characterize the act of goal setting of Serbian learners and provide a comparison with the results of other EFL learners. The analysis of the questionnaire based on one presented in Gaumer Erickson, Soukup, Noonan \& McGurn (2015), which was completed by 100 students, suggests that B1 students possess better values of the goal setting components than B2 students. Correlations between the components provide a large number of statistically significant results. What the goal setting theory implies is that students who are more successful in goal setting will achieve better results. Nevertheless, such an idea is not confirmed by our results since success in learning does not correlate with any of the goals setting components.
\end{abstract}

Key words: goal setting, components, Serbian EFL learners, proficiency level.

\section{KOMPONENTE POSTAVLJANJA CILJEVA: STUDIJA O SRPSKIM UČENICIMA ENGLESKOG KAO STRANOG}

APSTRAKT: Teorija o postavljanju ciljeva nastala je pre skoro tri decenije (Locke \& Latham 1990). Međutim, postavljanje ciljeva kod srpskih studenata koji uče engleski kao strani jezik još uvek nije istraživano. Cilj ovog rada jeste da okarakteriše čin postavljanja ciljeva kod srpskih učenika i poredi ove rezultate sa rezultatima drugih učenika engleskog. Analiza upitnika zasnovanog na onom koji je predstavljen u Gaumer Erikson, Sokup, Nunan i Makgern (Gaumer Erickson, Soukup, Noonan \& McGurn 2015), a koji je popunilo 100 studenata, navodi na zaključak da studenti nivoa B1 poseduju bolje vrednosti komponenata postavljanja ciljeva nego studenti nivoa B2. Korelacije između komponenata daju veliki broj statistički značajnih rezultata. Teorija o postavljanju ciljeva podrazumeva da će studenti koji su uspešniji u postavljanju ciljeva postići bolje rezultate. Ipak, naši rezultati ne potvrđuju ovu pretpostavku pošto uspeh u učenju ne korelira ni sa jednom od komponenata postavljanja ciljeva.

Ključne reči: postavljanje ciljeva, komponente, srpski učenici engleskog kao stranog, nivo znanja. 


\section{INTRODUCTION}

Goal setting plays an important role in all aspects of one's life, including learning a foreign language. It is an area in which the ones who are aware of the theory of goal setting can master language skills better than those who are not. Learners who set their goals and behave accordingly achieve the desired results. The essential precondition for goal setting is the motivation to learn. Motivated students are inclined to regard their learning process in terms of goals and exert effort which is necessary for attaining them. Apart from being committed, such students are likely to be self-efficacious since the positive past experience of setting and reaching their goals enables them a sufficient amount of belief in their own capabilities. It is generally believed that specific goals enhance productivity, as well as independence in learning, while striving towards two or more goals at the same time can bring about undesirable consequences.

In this paper we have made an attempt to explore the connection between gender, grades, years of learning English and proficiency level and the goal setting components, as well as the relationship between the goal setting components themselves. A considerable body of research has examined the goal setting components of people of different occupations living in different countries. However, the topic has not been investigated on a corpus of Serbian students learning English as a foreign language. Therefore, the paper provides empirical data which have the purpose to illustrate the behaviour of Serbian EFL students with respect to goal setting and confirm or reject the ideas that the goal setting theory consists of. In addition, the article enables a comparison with other works dealing with the same topic, which could provide a fuller picture of the place of goal setting in the EFL classroom.

The paper is organized in the following way: section 2 gives an overview of the elements of the goal setting theory that are relevant for this study; section 3 presents the methodology, including aims, instrument, participants and procedure; section 4 provides the statistically significant results and those that may be interesting to the reader; section 5 brings discussion of the results; finally, section 6 summarizes the most important results and concludes the paper.

\section{THE GOAL SETTING COMPONENTS}

The goal setting components measured by the instrument used for obtaining the results include the following: commitment, self-efficacy, goal specificity, goal conflict and autonomy. In order to be able to interpret the results for these elements, it is necessary to understand how each of them can be defined and in what way they are related to goal setting.

Commitment represents an integral part of the activity that one is performing in order to achieve their goal. Locke \& Latham (1990) equate 
commitment with determination to achieve a goal. Tubbs \& Ekeberg (1991) emphasize more subtle distinctions between commitment, determination and acceptance. According to them, commitment refers to intentions a person makes to attain a goal. Determination is the notion that stresses that these intentions continue to exist within a period of time. Acceptance is simply an agreement to begin an activity leading towards a goal. Regardless of the way in which it is defined, commitment cannot be separated from the action that a person performs with the aim to reach a goal; the action serves as the proof of goal commitment (Salancik 1977).

According to Bandura (1986), self-efficacy influences the choice of activities, effort expended, and persistence. Students who hold low self-efficacy for learning may avoid tasks while those who believe that they are efficacious are more likely to participate. When facing difficulties, learners with high self-efficacy expend greater effort and persist longer than students who doubt their capabilities. To indicate the importance of a relationship between goal setting and motivation, Schunk (1991) describes students' behaviour while acting towards reaching a goal. They are prone to feeling an initial sense of self-efficacy and exert the necessary commitment. In addition, they do the required tasks and adjust their behaviour so as to be able to achieve positive results. As indicated by Elliott \& Dweck (1988), monitoring goal progress enables students to strengthen their sense of self-efficacy, which implies the development of their skills (cited in Schunk 1991).

Locke et al. (1981: 4) define goal specificity as "the degree of quantitative precision with which the aim (goal) is specified." However, the role of goal specificity in the goal setting theory is still a bit confusing, since we do not have a clear picture about its effects on achieving a certain goal. It is argued that the main influence of goal specificity is on the performance level, but goal theory has actually never made any predictions about the independent effects of goal specificity (Locke et al. 1981).

What is highly accepted is that specific, difficult goals will lead to a better performance than specific, easy goals, but it is still not determined if specific, difficult goals will boost performance of an individual to a greater extent than it is the case with vague goals of the same difficulty (Klein, Whitener \& Ilgen 1990). The more specific goals become, the more focus in attention and action is necessary (Beehr \& Love 1983). Specific goals should help while choosing an appropriate strategy for achieving the goal because they hold more information and better illustrate what is expected from the task. On the other hand, when there is absence of a specific goal, there is a free exploration of a problem which can lead to attaining a variety of goals and this knowledge can be transferred when solving other similar problems (Vollmeyer, Burns \& Holyoak 1996).

Goal conflict occurs when a goal that a person wishes to achieve interferes with the attainment of at least one other goal that the person simultaneously wishes to achieve (Emmons et al. 1993), or, in other words, when two or more motives block each other. Emmons \& King (1988) found that individuals with more conflict 
between their goals tend to spend more time thinking about them, rather than acting on them (as cited in Boudreaux \& Ozer 2013). To avoid goal conflict, strategies of goal setting and goal planning should be used to implement a less stressful environment once a person has experienced goal conflict. In addition, goal structure is very important, which means that goals should be clearly defined; the role and contribution of each unit towards achieving the goal need to be recognized as well.

In learning, autonomy refers to students taking more control over their learning in and out of classroom, and autonomy in language learning is about people taking more control over the purposes for which they learn another language and the ways in which they learn them (Benson 2006). Social psychology regards autonomy as a characteristic which implies that a person strives towards personal achievement independence and has a predilection for solitude (Kingdon et al. 2017).

As suggested by Little (2006), the initial step that a learner needs to make in order to gain autonomy is to accept full responsibility for the process of learning as well as to be aware that nobody else can be the cause of success or failure. To accept responsibility means to learn how to analyze the process of learning "in a systematic, deliberate way" (Holec 1981: 3) - the skill which enables identifying positive and negative sides of the process and acting accordingly. In addition, Little indicates that "autonomous learners are motivated learners" (2006: 1). The connection between these two notions is important because it suggests that, due to a higher amount of motivation, autonomous learners are more likely to achieve their goals than those who are not.

In conclusion, the goal setting theory makes use of characteristics and patterns of behaviour that can be used as a predictor of one's success in goal attainment. Therefore, it is expected that a person who is committed, selfefficacious and autonomous will be able to attain his or her goals as opposed to the one who lacks high values of these elements. The role of goal specificity is not as clear as the role of other elements (although specific goals are expected to improve performance). Goal conflict is a goal setting component which has a negative impact on the activities that lead to optimal results.

\section{METHOD}

\subsection{Aims}

The study aims to answer the following research questions: 1) Is there any significant relationship between independent variables and the goal setting components?; 2) Are there any significant correlations between the goal setting components?; 3) How do our results differ from the results of other authors? Based on general beliefs, we formed the following hypotheses about the expected results: male students are more autonomous and self-efficacious; female students are more committed; students with higher grades are more committed and self-efficacious; students who learn English longer encounter less goal conflict; students who are 
committed are self-efficacious as well. In order to gather data about EFL students and be able to answer the research questions, we used a questionnaire described in the following section.

\subsection{Instrument}

The questionnaire presented in Gaumer Erickson, Soukup, Noonan \& McGurn (2015) includes statements expressing personal feelings, attitudes or characteristic behaviour related to goal setting. The items can be divided into groups based on the goal component that they measure (commitment, self-efficacy, goal specificity, goal conflict or autonomy). Commitment is measured by 11 items $(3,6,10,11,13,14,15,17,18,19,21)$, self-efficacy by means of 6 items $(4,5,16$, $20,22,23)$, goal specificity using 3 items $(1,2,12)$. Goal conflict and autonomy were tested with 2 items each (goal conflict: 8, 24; autonomy: 7, 9).

We translated the items into Serbian and adapted several of them to the context of learning a foreign language (see Appendix 1). For example, the item Winning means everything to me. was changed to Getting a good grade means everything to me. Some of the items were adjusted to the presumed interests of the participants, e.g. instead of the item I set short-term goals for myself such as finishing all my homework this week or finding transportation to the football game., the item we included in the questionnaire has the following form: I set short-term goals for myself such as finishing all my homework this week or watching a few episodes of a sitcom. Each statement is followed by a scale from 1 to 5 in which 1 means strongly agree, 2 - agree, 3 - neither agree nor disagree, 4 -disagree, 5 strongly disagree.

Apart from the items that were translated or adjusted from the original questionnaire, we included the items which the participants needed to complete with personal information (age and gender) and the information in connection with learning English as a foreign language (years of learning English, grade in the final examination and a deserved grade).

\subsection{Participants}

EFL students of the University of Novi Sad agreed to participate in the research by completing the questionnaire. The mean age of the participants was 20.18 years. The number of participants in the research was 100, of which there are 75 females $(75 \%)$ and 25 males (25\%). 50 participants (50\%) are estimated to be at B1 level and another half (50\%) at B2 level, according to the CEFR (Common European Framework of Reference).

\subsection{Procedure}

The participants were instructed to fill in the blanks with personal information and the information concerning English first. Afterwards, they were 
asked to choose and circle one of the options that best describes them with respect to goals. They were encouraged to work in their own time and ask questions if anything was unclear. The completed questionnaires were numbered from 1 to 100 . The data for each of the participants were entered into Microsoft Excel. Mean scores for every goal component were calculated, after which the data were copied into the program IBM SPSS Statistics 20, in which the final part of the analysis was undertaken.

\section{RESULTS}

The results are reported in three subsections according to the variables 'gender' and 'level' and correlations between the goal setting components. Since grade and years of learning English did not yield statistically significant results, nor showed any interesting tendencies, these variables are excluded from the paper.

\subsection{Gender}

In order to compare values of dependent variables between male and female students, we performed an independent samples T-test.

\begin{tabular}{|c|c|c|c|c|c|c|c|}
\hline Gender & & $\mathrm{N}$ & Mean & $\begin{array}{c}\text { Std. } \\
\text { Deviation }\end{array}$ & $\begin{array}{c}\text { Mean } \\
\text { Difference }\end{array}$ & $\mathrm{t}$ & $\mathrm{p}$ \\
\hline \multirow[t]{2}{*}{ Commitment } & Male & 25 & 2.45 & .68 & .01 & .090 & .929 \\
\hline & Female & 75 & 2.43 & .63 & & & \\
\hline \multirow[t]{2}{*}{ Self-efficacy } & Male & 25 & 2.55 & .89 & .28 & 1.489 & .140 \\
\hline & Female & 75 & 2.26 & .81 & & & \\
\hline \multirow{2}{*}{$\begin{array}{l}\text { Goal } \\
\text { specificity }\end{array}$} & Male & 25 & 2.77 & .74 & -.06 & -.291 & .772 \\
\hline & Female & 75 & 2.83 & .89 & & & \\
\hline \multirow[t]{2}{*}{ Goal conflict } & Male & 25 & 3.38 & 1.12 & -.27 & -1.259 & .211 \\
\hline & Female & 75 & 3.65 & .87 & & & \\
\hline \multirow[t]{2}{*}{ Autonomy } & Male & 25 & 2.18 & 1.11 & .19 & .792 & .430 \\
\hline & Female & 75 & 1.99 & 1.04 & & & \\
\hline
\end{tabular}

Table 1: Independent samples T-test (variable gender)

The statistical analysis shows that female students obtained higher scores ${ }^{1}$ for all goal setting components except for goal specificity (commitment: M: 2.45, F: 2.43; self-efficacy: M: 2.55, F: 2.26; goal specificity: M: 2.77, F: 2.83; goal conflict: M: 3.38, F: 3.65; autonomy: M: 2.18, F: 1.99). Therefore, female students are more committed, self-efficacious, face less goal conflict and exhibit more autonomy with respect to learning English, while male students tend to set specific

\footnotetext{
${ }^{1}$ Since number 1 on a scale stands for strongly agree and number 5 for strongly disagree, the lower mean result actually represents a higher value.
} 
goals to a greater degree. However, the differences that arise between the two genders are not statistically significant since the $p$ value is higher than 0.05 for all variables. Hence, the null hypothesis can be accepted.

\subsection{Level}

We conducted the same type of test to receive data about the relationship between values for goal setting components in students divided into two groups according to their level of proficiency in English.

Mean scores indicate that $\mathrm{B} 1$ students express higher commitment $(\mathrm{MD}=-$ 0.27 ), higher self-efficacy ( $\mathrm{MD}=-0.48$ ), tend to set specific goals more often ( $\mathrm{MD}=-$ $0.49)$, encounter less goal conflict $(\mathrm{MD}=0.39)$ and possess more autonomy as concerns the act of goal setting $(\mathrm{MD}=-0.35)$. The differences in results which are statistically significant are the following: commitment $(\mathrm{t}=-2.120, \mathrm{p}=0.037)$, selfefficacy $(\mathrm{t}=-2.997, \mathrm{p}=0.004)$, goal specificity $(\mathrm{t}=-2.952, \mathrm{p}=0.004)$, goal conflict $(\mathrm{t}=2.103, \mathrm{p}=0.038)$. We can observe that proficiency level serves as an important factor in differentiating between students regarding goal setting, as opposed to their gender.

\begin{tabular}{|c|c|c|c|c|c|c|c|}
\hline \multicolumn{2}{|c|}{ Level } & $\mathrm{N}$ & Mean & $\begin{array}{c}\text { Std. } \\
\text { Deviation }\end{array}$ & $\begin{array}{c}\text { Mean } \\
\text { difference }\end{array}$ & $\mathrm{t}$ & $\mathrm{p}$ \\
\hline \multirow[t]{2}{*}{ Commitment } & B1 & 50 & 2.30 & .44 & -.27 & -2.120 & .037 \\
\hline & B2 & 50 & 2.57 & .78 & & & \\
\hline \multirow[t]{2}{*}{ Self-efficacy } & $\mathrm{B} 1$ & 50 & 2.09 & .62 & -.48 & -2.997 & .004 \\
\hline & B2 & 50 & 2.57 & .95 & & & \\
\hline \multirow{2}{*}{$\begin{array}{l}\text { Goal } \\
\text { specificity }\end{array}$} & B1 & 50 & 2.57 & .80 & -.49 & -2.952 & .004 \\
\hline & $\mathrm{B} 2$ & 50 & 3.06 & .85 & & & \\
\hline \multirow[t]{2}{*}{ Goal conflict } & B1 & 50 & 3.78 & .86 & .39 & 2.103 & .038 \\
\hline & $\mathrm{B} 2$ & 50 & 3.39 & .99 & & & \\
\hline \multirow[t]{2}{*}{ Autonomy } & B1 & 50 & 1.86 & .96 & -.35 & -1.674 & .097 \\
\hline & B2 & 50 & 2.21 & 1.12 & & & \\
\hline
\end{tabular}

Table 2: Independent samples T-test (variable level)

Mean scores indicate that $\mathrm{B} 1$ students express higher commitment (MD=0.27 ), higher self-efficacy ( $\mathrm{MD}=-0.48$ ), tend to set specific goals more often ( $\mathrm{MD}=-$ $0.49)$, encounter less goal conflict $(\mathrm{MD}=0.39)$ and possess more autonomy as concerns the act of goal setting $(\mathrm{MD}=-0.35)$. The differences in results which are statistically significant are the following: commitment $(\mathrm{t}=-2.120, \mathrm{p}=0.037)$, selfefficacy $(\mathrm{t}=-2.997, \mathrm{p}=0.004)$, goal specificity $(\mathrm{t}=-2.952, \mathrm{p}=0.004)$, goal conflict $(\mathrm{t}=2.103, \mathrm{p}=0.038)$. We can observe that proficiency level serves as an important factor in differentiating between students regarding goal setting, as opposed to their gender. 


\subsection{Correlations between the goal setting components}

A Pearson correlation test was employed to answer the second research question. While correlations between the grades that students received in their final examination in EFL and years they spent learning the language, on the one hand, and between the goal setting components on the other did not yield statistically significant results, the analysis shows many statistically significant results concerning correlations between dependent variables themselves.

\begin{tabular}{|c|c|c|c|c|c|c|}
\hline & & Commitment & $\begin{array}{c}\text { Self- } \\
\text { efficacy }\end{array}$ & $\begin{array}{c}\text { Goal } \\
\text { specificity }\end{array}$ & $\begin{array}{c}\text { Goal } \\
\text { conflict }\end{array}$ & Autonomy \\
\hline \multirow[t]{2}{*}{ Commitment } & $\mathrm{r}$ & 1 & $.809^{* * *}$ & $.260^{* * *}$ & $-.453^{* *}$ & $.631^{* * *}$ \\
\hline & $\mathrm{p}$ & & .000 & .009 & .000 & .000 \\
\hline \multirow[t]{2}{*}{ Self-efficacy } & $\mathrm{r}$ & $.809^{* * *}$ & 1 & $.263^{* *}$ & $-.480^{* * *}$ & $.564^{* *}$ \\
\hline & $\mathrm{p}$ & .000 & & .008 & .000 & .000 \\
\hline \multirow{2}{*}{$\begin{array}{l}\text { Goal } \\
\text { specificity }\end{array}$} & $\mathrm{r}$ & $.260^{* * *}$ & $.263^{* *}$ & 1 & $-.254^{*}$ & .173 \\
\hline & $\mathrm{p}$ & .009 & .008 & & .011 & .085 \\
\hline \multirow[t]{2}{*}{ Goal conflict } & $r$ & $-.453^{* * *}$ & $-.480^{* * *}$ & $-.254^{*}$ & 1 & $-.635^{\text {** }}$ \\
\hline & $\mathrm{p}$ & .000 & .000 & .011 & & .000 \\
\hline \multirow[t]{2}{*}{ Autonomy } & $\mathrm{r}$ & $.631^{\text {** }}$ & $.564^{\text {** }}$ & .173 & $-.635^{* *}$ & 1 \\
\hline & $\mathrm{p}$ & .000 & .000 & .085 & .000 & \\
\hline \multicolumn{7}{|c|}{ **. Correlation is significant at the 0.01 level (2-tailed). } \\
\hline
\end{tabular}

Table 3: Correlations between the goal setting components

Commitment is positively correlated with self-efficacy $(\mathrm{r}=0.809, \mathrm{p}=0.000)$, goal specificity $(\mathrm{r}=0.260, \mathrm{p}=0.009)$, autonomy $(\mathrm{r}=0.631, \mathrm{p}=0.000)$ and negatively correlated with goal conflict $(\mathrm{r}=-0.453, \mathrm{p}=0.000)$. Apart from being committed, students who are self-efficacious also tend to set specific goals $(r=0.263, p=0.008)$, express more autonomy $(\mathrm{r}=0.564, \mathrm{p}=0.000)$ and deal with less goal conflict $(\mathrm{r}=-$ $0.480, \mathrm{p}=0.000)$. As it could have been expected, goal conflict is negatively correlated with other two variables as well: goal specificity $(\mathrm{r}=-0.254, \mathrm{p}=0.011)$ and autonomy $(\mathrm{r}=-0.635, \mathrm{p}=0.000)$. It is worth mentioning that the correlation between goal conflict and goal specificity is the only result which is statistically significant at the level of this sample, while other statistically significant results produce generalizations that can be applied on a wider population of learners. The only correlation which does not bring about a statistically significant result is that between goal specificity and autonomy, which means that the fact that a person shows preference for setting specific goals cannot tell us anything about how independent he or she is. 


\section{DISCUSSION}

In this section, we will discuss the most interesting and statistically significant results obtained in the analysis and compare them to some other findings in the literature relevant for the goal setting theory.

Gender is usually perceived as the category which highly influences learning foreign languages. Females are generally believed to be more skillful in this respect. The information which can be viewed as the predictor of women's success in learning is the ratio of female students to male students who decide to take English language courses. Since willingness to learn can be regarded as a prerequisite for goal commitment, our hypothesis was that females would outperform their male colleagues as concerns this variable. On the other hand, we hypothesized that male students would display more autonomy and self-efficacy due to deeply-rooted social beliefs according to which men generally demonstrate more independence and self-confidence in life. Nevertheless, even though the differences in our results show the tendency of female learners to have better scores for all goal setting components (higher values for commitment, self-efficacy, goal specificity and autonomy and lower values for goal conflict), they are not statistically significant, which is the reason why we reject the hypotheses about gender differences. In this way, our study is similar to those conducted by Nematipour (2012) and Hashemi \& Ghanizadeh (2011), which do not report significant results concerning the relationship between gender and autonomy and gender and self-efficacy, respectively. Our results about the lack of connection between gender and commitment do not accord with the findings published in Salem (2006), which reveal that female students make more effort than their male colleagues as regards learning English as a foreign language.

The variable 'level' proves to be the independent variable which brings the largest number of statistically significant results according to which students at B1 level are more successful at the activity of setting goals than it is the case with B2 students - the only goal setting component which did not lead to statistically significant results is autonomy; interestingly, the results presented in Liu (2012) indicate that EFL students' autonomy increases with their language proficiency. The reason for statistically significant results that we obtained may be the distinction between skills required for different CEFR levels. We presume that lower values for commitment, self-efficacy and goal specificity and higher values for goal conflict in B2 students are the repercussion of the requirements that B2 level imposes. The explanation that we can offer is that a large amount of effort that one needs to exert to expand vocabulary and acquire more complex grammatical structures, among other skills necessary for responding to B2 level demands, may be perceived as too challenging tasks by EFL learners and induce a lack of motivation needed for both setting and achieving goals.

Surprisingly, grades and years of learning English do not correlate with any of the goal setting components, which is why the hypothesis that students with 
higher grades will be more committed and self-efficacious can be rejected, as well as the one which states that students who have spent a longer period of time learning English will encounter less goal conflict. Therefore, there is no relationship between goal setting and success in learning, nor between goal setting and language experience.

Correlations between dependent variables provide results which can be seen as logical since they prove that there is a link between the goal setting components that are deemed to be positive. Thus, students in our sample who are committed are also self-efficacious, which is why we accept the hypothesis that was formulated. Such students possess the habit of setting specific goals, which is another trait of students successful in goal setting activities. Another factor that increases the effectiveness of goal setting is the tendency of learners to set goals on their own since this does not make them feel obligated to attain them. It is, therefore, reasonable why there is a positive relationship between the above-mentioned variables and autonomy. On the other hand, the component which renders goal setting less effective is goal conflict. It does not occur in the process of learning for students who are committed, self-efficacious, autonomous and inclined to goal specificity, while it does represent a negative characteristic of learning for students who lack higher values for other goal setting components.

\section{CONCLUSION}

The current study shows the statistically significant difference between the goal setting components for students at B1 and B2 level, according to which B1 students are characterized with more commitment, self-efficacy, goal specificity and less goal conflict. The study does not yield statistically significant results concerning goal components for variables 'gender', 'grade' and 'years of learning English'. Variables 'commitment', 'self-efficacy', 'goal specificity' and 'autonomy' are positively correlated with each other (excluding goal specificity and autonomy) and negatively correlated with the variable 'goal conflict'.

One of the limits of the research (which can be ascribed to the methodology of using the questionnaire) is that students' beliefs about their behaviour with respect to goal setting may not always reflect the way they actually behave. For instance, some students may consider themselves independent and insusceptible to parents' influence, but in fact they may be less autonomous than that they think.

What the goal setting theory implies is that high scores for all goal setting components except for goal conflict will help learners to achieve the desired results. Therefore, it is expected that students with higher grades are characterized with better goal setting habits. Even though our results regarding proficiency level and the relationship between the goal setting components are statistically significant, there is no statistically significant result for variable 'grade' which represents success in learning EFL. For this reason, the idea that teachers should familiarize their students with the importance of the goal setting theory for the anticipated 
benefits does not seem necessary, judging from the results. Nevertheless, since the sample analyzed in this paper consists of 100 students, we would need a larger number of participants to corroborate the findings.

\section{REFERENCES}

Bandura, A. (1986). "The Explanatory and Predictive Scope of Self-efficacy Theory". Journal of Social and Clinical Psychology, 4(3): 359-373.

Beehr, T. A., \& Love, K. G. (1983). "A Meta-model of the Effects of Goal Characteristics, Feedback, and Role Characteristics in Human Organizations". Human Relations, 36(2): 151-166.

Benson, P. (2006). Learner Autonomy 8: Insider Perspectives on Autonomy in Language Teaching and Learning. Dublin: Authentik.

Boudreaux, M. J., \& Ozer, D. J. (2013). "Goal Conflict, Goal Striving, and Psychological Well-being". Motivation and Emotion, 37(3): 433-443.

Emmons, R. A., King, L. A., \& Sheldon, K. (1993). Goal Conflict and the Selfregulation of Action. In D. M. Wegner \& J. W. Pennebaker (Eds.), Century Psychology Series. Handbook of Mental Control: 528-551.

Gaumer Erickson, A.S., Soukup, J.H., Noonan, P.M., \& McGurn, L. (2015). Goal Setting Questionnaire. Lawrence, KS: University of Kansas, Center for Research on Learning.

Hashemi, M. R., \& Ghanizadeh, A. (2011). "Emotional Intelligence and Selfefficacy: A Case of Iranian EFL University Students". International Journal of Linguistics, 3(1): 1-16.

Holec, H. (1981). Autonomy and Foreign Language Learning. Oxford: Pergamon Press.

Kingdon, D., Maguire N., Stalmeisters D., \& Townend, M. (2017). CBT Values and Ethics. London: SAGE Publications Ltd.

Klein, H. J., Whitener, E. M., \& Ilgen, D. R. (1990). "The Role of Goal Specificity in the Goal-setting Process". Motivation and Emotion, 14(3): 179-193.

Little, D. (2006). "Learner autonomy: Drawing together the threads of selfassessment, goal setting and reflection". Accessed 25/06/2018. URL: https://archive.ecml.at/mtp2/ELP_TT/ELP_TT_CDROM/DM_layout/00_1 0/06/06\%20Supplementary\%20text.pdf.

Liu, H. J. (2012). "Understanding EFL Undergraduate Anxiety in Relation to Motivation, Autonomy, and Language Proficiency". Electronic Journal of Foreign Language Teaching, 9(1): 123-139.

Locke, E. A., \& Latham, G. P. (1990). A Theory of Goal Setting \& Task Performance. Englewood Cliffs, NJ, US: Prentice-Hall, Inc.

Locke, E. A., Shaw, K. N., Saari, L. M., \& Latham, G. P. (1981). "Goal Setting and Task Performance: 1969-1980”. Psychological Bulletin, 90(1): 125-152. 
Nematipour, M. (2012). “A Study of Iranian EFL learners' Autonomy Level and Its Relationship with Learning Style”. English Linguistics Research, 1(1): 126136.

Salancik, G. (1977). "Commitment and the Control of Organizational Behavior and Belief", in New Directions in Organizational Behavior, ed. B. M. Staw \& G. R. Salancik (Chicago: St. Clair Press): 1-54.

Salem, N. M. (2006). The Role of Motivation, Gender, and Language Learning Strategies in EFL Proficiency. Doctoral dissertation. American University of Beirut, Department of Education.

Schunk, D. H. (1991). "Self-efficacy and Academic Motivation". Educational Psychologist, 26, 207-231.

Tubbs, M. E., \& Ekeberg, S. E. (1991). "The Role of Intentions in Work Motivation: Implications for Goal-setting Theory and Research". Academy of Management Review, 16(1): 180-199.

Vollmeyer, R., Burns, B. D., \& Holyoak, K. J. (1996). "The Impact of Goal Specificity on Strategy Use and the Acquisition of Problem Structure". Cognitive Science, 20(1): 75-100.

\author{
Aleksandar M. Živanović \\ Univerzitet u Novom Sadu \\ Filozofski fakultet \\ Jezik i književnost \\ Mirjana D. Subotin \\ Univerzitet u Novom Sadu \\ Filozofski fakultet \\ Engleski jezik i književnost
}

\title{
KOMPONENTE POSTAVLJANJA CILJEVA: STUDIJA O SRPSKIM UČENICIMA ENGLESKOG KAO STRANOG
}

\section{Sažetak}

Teorija o postavljanju ciljeva nastala je pre skoro tri decenije (Locke \& Latham 1990). Međutim, postavljanje ciljeva kod srpskih studenata koji uče engleski kao strani jezik još uvek nije istraživano. Cilj ovog rada jeste da rasvetli vezu između srpskih učenika i komponenata postavljanja ciljeva (posvećenost, samoefikasnost, specifičnost cilja, konflikt ciljeva i autonomija), kao i da omogući poređenje sa rezultatima drugih autora. Sa tom namerom preveli smo i prilagodili upitnik (Gaumer Erickson, Soukup, Noonan \& McGurn 2015) i podelili ga studentima Filozofskog fakulteta u Novom Sadu koji uče engleski jezik kao strani. U istraživanju je učestvovalo 100 studenata starosti 20,18 godina; broj ženskih studenata je bio procentualno veći (75\%-25\%) dok je odnos procenata u pogledu nivoa znanja bio podjednak (50\% studenata pripada nivou B1, a 50\% nivou B2, prema Zajedničkom evropskom okviru za žive jezike). Analiza dobijenih rezultata govori da između muških i ženskih studenata ne postoji statistički značajna razlika kada je reč o teoriji 
postavljanja ciljeva. Takođe, varijable ocena, godine starosti i godine učenja jezika ne daju statistički značajne rezultate kad se koreliraju sa komponentama postavljanja ciljeva. Sa druge strane, nivo znanja je kategorija koja dovodi do statistički znalajnih rezultata pošto studenti nivoa B1 pokazuju bolje rezultate u pogledu posvećenosti, samoefikasnosti, specifičnosti i konflikta ciljeva. Kao razlog za ovakve rezultate mogu se navesti zahtevniji zadaci sa kojima se studenti nivoa B2 suočavaju, koji mogu dovesti do gubitka motivacije neophodne za postavljanje i ostvarivanje ciljeva. Varijable posvećenost, samoefikasnost, specifičnost cilja i autonomija su u pozitivnoj korelaciji jedne sa drugima (ne računajući specifičnost cilja i autonomiju), a u negativnoj korelaciji sa varijablom konflikt ciljeva. Ovakvi rezultati su mogli biti očekivani s obzirom na to da je verovatno da će student koji se odlikuje jednom pozitivnom karakteristikom posedovati i druge. Jedina korelacija koja ne proizvodi statistički značajan rezultat jeste korelacija između specifičnosti cilja i autonomije, što ukazuje na odsustvo povezanosti između toga koliko je učenik sklon postavljanju specifičnih ciljeva sa jedne strane i u kojoj meri je nezavistan u učenju sa druge.

Ključne reči: postavljanje ciljeva, komponente, srpski učenici engleskog kao stranog, pol, nivo znanja. 
APPENDIX 1

Pol Godine Godine učenja engleskog jezika

Ocena na poslednjem ispitu iz engleskog jezika

Ocena koju smatram da zaslužujem

Za svaku rečenicu zaokružite jedan odgovor koji vas najbolje opisuje.

1 - Potpuno se slažem 2 - Slažem se 3 - Neodlučan sam 4 - Ne slažem se 5 - Potpuno se ne slažem

1. Sebi postavljam kratkoročne ciljeve, npr. da završim sve domaće zadatke ove nedelje ili da

odgledam nekoliko epizoda serije. $\begin{array}{lllll}1 & 2 & 3 & 4 & 5\end{array}$

2. Sebi postavljam dugoročne ciljeve, npr. da očistim godinu ili da diplomiram. $\begin{array}{llll}1 & 2 & 3 & 4\end{array}$ 5

3. Postavljam ciljeve da ostvarim ono što smatram bitnim. $\begin{array}{lllll}1 & 2 & 3 & 4 & 5\end{array}$

4. Zamišljam kakav će život biti kada ostvarim cilj. $\begin{array}{lllll}1 & 2 & 3 & 4 & 5\end{array}$

5. Moji ciljevi me čine organizovanim i fokusiranim. $\begin{array}{lllll}1 & 2 & 3 & 4 & 5\end{array}$

6. Moji ciljevi mi znače. $12 \begin{array}{lll}3 & 4 & 5\end{array}$

7. Moji ciljevi su zasnovani na mojim ličnim interesovanjima i planovima za budućnost. 1

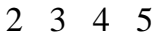

8. Teško mi je da odredim sebi ciljeve. $\begin{array}{lllll}1 & 2 & 3 & 4 & 5\end{array}$

9. Moji ciljevi su uglavnom zasnovani na onome što moja porodica i nastavnici smatraju bitnim. $1 \quad 2 \quad 3 \quad 4 \quad 5$

10. Uvek pokušavam da naučim nešto novo. $\begin{array}{lllll}1 & 2 & 3 & 4 & 5\end{array}$

11. Dajem sve od sebe da poboljšam svoje sposobnosti. $1 \quad 2 \quad 3 \quad 4 \quad 5$

12. Kada učim nešto, pravim male ciljeve da bih pratio napredak. $\begin{array}{lllll}1 & 2 & 3 & 4 & 5\end{array}$

13. Dobra ocena mi je najbitnija. $12 \begin{array}{llll}1 & 2 & 4 & 5\end{array}$

14. Iako želim da dobijem dobru ocenu, zadovoljan sam ako sam ostvario napredak. 1223 45

15. Stalo mi je da budem bolji od drugih ljudi. $\begin{array}{lllll}1 & 2 & 3 & 4 & 5\end{array}$

16. Na osnovu svega što znam o sebi, verujem da mogu da ostvarim svoje ciljeve. 1223 45

17. Istražujem šta je potrebno da bi se ostvario cilj pre nego što ga odredim. $\begin{array}{lllll}1 & 2 & 3 & 4 & 5\end{array}$

18. Kada određujem ciljeve, razmišljam o preprekama koje bi mogle da se pojave. 123 45

19. Kada mi se desi neuspeh ili nešto ne uradim dobro, učim na svojim greškama. 1223 45

20. Mogu uspešno da predvidim svoje ocene na testovima. $\begin{array}{lllll}1 & 2 & 3 & 4 & 5\end{array}$

21. Iskustvo mi govori kada treba da isprobam novu strategiju. $\begin{array}{lllll}1 & 2 & 3 & 4 & 5\end{array}$

22. Kada mi roditelji ili nastavnici kažu da mogu da uradim nešto, motivisan sam da uspem u tome. $\begin{array}{lllll} & 2 & 3 & 4 & 5\end{array}$

23. Kada postavim cilj, uspem da ga ostvarim. $\begin{array}{lllll}1 & 2 & 3 & 4 & 5\end{array}$

24. Postavljam ciljeve koje nisam u stanju da ostvarim. $\begin{array}{lllll}1 & 2 & 3 & 4 & 5\end{array}$

Received: 18 April 2018

Accepted: 27 June 2018 